\title{
Calcium and Phosphorus Utilization on Rats with Induced Cerebral Palsy
}

\author{
Hoda S. Ibrahim, Naeem M. Rabeh and Fatma N. Ahmed* \\ Nutrition and Food Science Department, Faculty of Home Economics, Helwan University, Egypt
}

*Corresponding Author: Fatma N. Ahmed, Nutrition and Food Science Department, Faculty of Home Economics, Helwan University, Egypt, Email: fatmanaserosman@gmail.com

\begin{abstract}
Cerebral palsy $(C P)$ is characterized by motor impairment and can present with global physical and mental dysfunction. The aim of the present study was to investigate the utilization of calcium and phosphorus on rats with induced CP. Forty-five adult male albino rats weighing $180 \pm 5$ gm were divided into groups. The 1st group ( $n=6)$ was fed on the basal diet (-ve control). The $2 n d$-7thgroups $(n=39)$ groups were injected with $15 \mu \mathrm{l}$ of the ethanol and $50 \mathrm{mg} / \mathrm{b} . \mathrm{w}$ of sodium phenytoin for CP induction. The 2nd group was +ve control. Group 3 was fed on basel diet supplemented with vitamin D3 at level of $600 \mathrm{IU} \mathrm{kg} / \mathrm{b} . \mathrm{w}$. Groups 4-5 were fed on diet supplemented with $40 \mathrm{mg} \& 120 \mathrm{mg}$ of calcium (levell and 2), respectively. Group 6 was fed on diet supplemented with level 1 Ca $(40 \mathrm{mg})$ with vitamin D supplementation, while group 7 was fed on diet supplemented with level $2 \mathrm{Ca}$ with vitamin $\mathrm{D}$ addition. At the end of the experimental period (10 weeks), rats were scarified. Biochemical analysis of the tested parameters were determined. Results indicated that diet supplementation with calcium and/or with vitamin D separately or in combination significantly increased the final body weight and body weight gain \%, as well as FER in all treated groups compared to the +ve control group. Liver functions, data revealed that feeding rats diets supplemented with Ca with / without vitamin D had improved liver functions by decreasing its elevated levels due to CP induction. Serum Ca and phosphorus $(P)$ concentrations of $C P$ rats were increased because of ingestion of diets supplemented with $\mathrm{Ca}$ and vitamin $D$ in all tested groups. Consequently, Ca/P ratio of CP rats was improved. In addition, serum $A L P$ and PTH concentrations of CP rats were improved. Data of our study revealed that diet supplementation with $C a$ and vitamin $D$ at the tested levels improved bone mineral density for $C P$ rats. The best improvement was seen when diet contains the highest level of Ca in addition to vitamin D. However, bone minerals content of the +ve control group showed significant reduction. It could be concluded from our study that ingestion of diets supplemented with Ca and vitamin D had beneficial effects on utilization of Ca and P and its ratio of CP rats. Thus, results of the current study recommend that vitamin $D$ and calcium supplementation at the tested levels could be worthy treating for CP patients.
\end{abstract}

Keywords: cerebral palsy, calcium, phosphorus, sodium phenytoin, bone mineral content, calcium/ phosphorus ratio

\section{INTRODUCTION}

Cerebral palsy (CP) is a group of disorders of the development of movement and posture, causing activity limitation that is attributed to non-progressive disturbances that occurred in the developing fetal or infant brain. This group of syndromes ranges in severity and is the result of a variety of etiologies occurring in the prenatal, perinatal or postnatal period. $\mathrm{CP}$ is the most common form of chronic motor disability in children. Other causes of disability in children include prolonged immobilization, nutritional factors, pubertal disorder and chronic use of anticonvulsants. All these factors may be related to impairment of normal bone development. Low calcium intake is common in $\mathrm{CP}$ patients and may contribute to poor

ARC Journal of Nutrition and Growth mineralization of bone matrix. Consequently, children with severe $\mathrm{CP}$ are at risk for developing low bone mineral density (BMD) and low-impact fractures (Nikam et al., 2019).

Vitamin D is essential for normal skeletal development, mineralization, growth and for maintenance of skeletal health throughout life, and those assessed vitamin D status and optimal means of improving status in these patient populations Vitamin D promotes calcium absorption from the intestine. Adequate vitamin $\mathrm{D}$ concentrations prevent bone loss and decrease fracture risk in the elderly (Arslan et al., 2018).

Calcium is essential for normal bone health at all ages. During childhood, calcium is needed for skeletal growth and in adulthood for maintenance of bone mass and content. 
Inadequate calcium intake results in decreased calcium absorption in the intestine, low levels of ionized calcium, and increased secretion of PTH (Peacock, 2010).

Many studies report that high $\mathrm{P}$ intake is harmful to bone health in subjects whose dietary $\mathrm{Ca}$ : $\mathrm{P}$ ratio is extremely low. However, there is strong evidence that high $\mathrm{P}$ intake has no negative impact on $\mathrm{Ca}$ balance in normal subjects with appropriate dietary $\mathrm{Ca}$ and $\mathrm{P}$ intakes (Lee and Cho, 2015).

Therefore, our study was conducted to investigate the effect of dietary calcium and vitamin D supplementation on calcium and phosphorus utilization on rats with induced cerebral palsy.

\section{Materials ANd Methods}

\subsection{MATERIALS}

Casein, all vitamins, calcium phosphate, minerals, ethanol, L.cystine and choline bitartrate were obtained from El-Gomhoria Company, Cairo, Egypt. Capsules of cholecalciferol (vitamin D3) at concentration of 1000 IU and sodium phenytoin (PHT) at concentration of $50 \mathrm{mg}$ were obtained from Delmar and Attallah Pharmacy, Cairo, Egypt.

Starch, corn oil, and sucrose were obtained from the local market Kits for blood analysis were purchased from local distributer (Sigma Chemical), Cairo, Egypt.

Animals: A total number of forty five adult male Albino rats (Sprague -Dawley strain) weighing $180 \pm 5 \mathrm{gm}$, were purchased from the Animal House of Helwan Farm, Helwan, Egypt.

\subsection{METHODS}

\subsubsection{Induction of Cerebral Palsy (CP) in Rats}

The left pyramidal tract of adult SpragueDawley rats was placed on sterile operation table under intraperitoneal anesthesia. Based on the rat brain stere-otaxic map, a 1-mm hole was made $10 \mathrm{~mm}$ posterior to bregma and $0.8 \mathrm{~mm}$ left of sagittal suture. A micro syringe was inserted perpendicularly to the surface of the brain to a depth of $9.7 \mathrm{~mm}$, and $15 \mu \mathrm{L}$ of ethanol was slowly injected to establish a rat model of spastic cerebral palsy as stated by Yadong $\boldsymbol{e t}$ al., (2013). Rats with CP then received phenytoin tablets in concentration of $50 \mathrm{mg}$ at the level of $20 \mathrm{mg} / \mathrm{ml} / \mathrm{kg}$ b.w to alleviate the symptoms of CP.

\subsubsection{Diet Composition and Experimental Animal Design}

The basal diet was formulated according to AIN-93M diet (Reeves, et al., 1993). Calcium carbonate and phenytoin were dissolved in distilled water and received by oral tube according to body weight of rats. Capsules of cholecalciferol (vitamin D3) was dissolved in corn oil and administrated with oral tube according to body weight of rats.

Forty five adult male Albino rats were housed in well- aerated cages under hygienic conditions and were fed on the basal diet for one week for adaptation. After this period, rats were divided into groups as follows: The first main group $(n=$ 6) was fed on basal diet and served as a negative control group (-ve). The rest of the rats (39 rats) were injected with $15 \mu \mathrm{L}$ of ethanol for induction of $\mathrm{CP}$. Three rats were scarified and the femur bone was taken to insure the induction of the $\mathrm{CP}$ using DEXA examination. Then rats were divided into six groups (6 rats each) as follows:

Group (1): Normal rats were fed on basal diet and served as a negative control group (-ve).

Group (2): Rats with CP were fed on basal diet (+ve control).

Group (3): Rats with CP were fed on basal diet and given daily vitamin D3 (600 IU/ kg. b. w) orally.

Group (4): Rats with CP were fed on basal diet supplemented with $40 \mathrm{mg}$ calcium phosphate (level1).

Group (5): Rats with CP were fed on basal diet supplemented with $120 \mathrm{mg}$ calcium phosphate (level 2).

Group (6): Rats with CP were fed on basal diet supplemented with $40 \mathrm{mg}$ calcium phosphate (level1) and Vitamin D.

Group (7): Rats with CP were fed on daily basal diet supplemented with $120 \mathrm{mg}$ calcium phosphate (level2) and Vitamin D.

At the end of the experimental period (10 weeks), rats were anesthetized with diethyl ether after fasting for $12 \mathrm{~h}$ and blood samples were taken. Then serum was carefully separated into vacuum tubes and kept frozen until biochemical analysis. Femur bones were removed from each rat for DEXA analysis.

\subsubsection{Biological Evaluation}

Biological Evaluation: feed intake (FI), feed efficiency ratio (FER) and body weight gain percent (BWG\%) were determined according to Hemdanand Abdulmaguid, (2018) using the following equation:

$$
B W G \%=\frac{\text { Final body weight }(g)-\text { Initial body weight }(g)}{\text { Initial body weight }(g)}
$$

$\boldsymbol{F E R}=$ Body weight gain $(g) /$ Feed intake $(g)$ 


\subsubsection{Biochemical Analysis}

Serum calcium content was determined according to (Gosling, 1986). Serum phosphorus content was determined according to (Fogg and Wilkinson, 1958). Serum alkaline phosphates was determined by immunosorbent assay according to the method described by Roy, (1970). Alanine aminotransferase (ALT) was determined by immunosorbent assay according to the method described by Thefeld, (1974). Aspartate aminotransferase (AST) was determined by immunosorbent assay according to the method described by Thefeld, (1974). Serum parathyroid hormone was determined by immunosorbent assay according to the method described by Henderson et al., (1990).

\subsubsection{Bone Mineral Content}

The density of bone in the right femur was determined by DEXA UNITE (LUNAR OX IQ 4716) according to the method of EL- Adawy, (1986)

\subsubsection{Statistical Analysis}

The Results were expressed as means \pm standard error (SE). The obtained results were analyzed according to SPSS program, Version (20). Analysis of variance (ANOVA) test was used to compare results among groups and $\mathrm{P} \leq 0.05$ was considered significant (Snedecor and Cochran, 1980).

Table1. Effect of diets supplemented with Ca and Vitamin D on body weight, feed intake(FI) and feed efficacy ratio(FER) of Cerebral Palsy rats

\begin{tabular}{|l|c|c|c|c|c|}
\hline \multirow{2}{*}{ Groups } & \multicolumn{4}{|c|}{ Parameters } \\
\cline { 2 - 6 } & IBW (g) & FBW (g) & BWG\% & FI (g/day) & FER \\
\hline Control (-Ve) & $183 \pm 1.96^{\mathrm{a}}$ & $262 \pm 2.30^{\mathrm{a}}$ & $43 \pm 1.76^{\mathrm{a}}$ & 19.10 & $0.05 \pm 0.001^{\mathrm{a}}$ \\
\hline Control (+Ve) & $182 \pm 2.03^{\mathrm{a}}$ & $192 . \pm 1.71^{\mathrm{e}}$ & $5 \pm 0.48^{\mathrm{e}}$ & 11.00 & $0.01 \pm 0.0009^{\mathrm{d}}$ \\
\hline Vitamin D & $180 \pm 1.02^{\mathrm{a}}$ & $205 \pm 2.08^{\mathrm{d}}$ & $13 \pm 1.04^{\mathrm{d}}$ & 13.70 & $0.02 \pm 0.001^{\mathrm{c}}$ \\
\hline Level 1 Ca & $184 \pm 1.24^{\mathrm{a}}$ & $240 \pm 5.41^{\mathrm{c}}$ & $29 \pm 2.28^{\mathrm{c}}$ & 14.00 & $0.05 \pm 0.004^{\mathrm{ab}}$ \\
\hline Level 2 Ca & $185 \pm 1.82^{\mathrm{a}}$ & $236 \pm 1.52^{\mathrm{c}}$ & $27 \pm 1.46^{\mathrm{c}}$ & 15.00 & $0.04 \pm 0.002^{\mathrm{b}}$ \\
\hline Level (1) Ca +Vt.D & $183 \pm 1.96^{\mathrm{a}}$ & $238 \pm 2.88^{\mathrm{c}}$ & $30 \pm 2.71^{\mathrm{c}}$ & 15.30 & $0.04 \pm 0.003^{\mathrm{ab}}$ \\
\hline Level (2) Ca + Vt.D & $183 \pm 2.70^{\mathrm{a}}$ & $249 \pm 0.75^{\mathrm{b}}$ & $35 \pm 2.23^{\mathrm{b}}$ & 15.50 & $0.05 \pm 0.002^{\mathrm{a}}$ \\
\hline
\end{tabular}

*Values are expressed as means $\pm S E$.

*Values at the same column with different letters are significantly different at $P<0.05$.

$* \boldsymbol{I B} \boldsymbol{W}=$ Initial body weight, $\boldsymbol{F} \boldsymbol{B} \boldsymbol{W}=$ final body weight, $\boldsymbol{B} \boldsymbol{W} \boldsymbol{G} \%=$ Body weight gain percent, $\boldsymbol{F I}=$ feed intake, $\boldsymbol{F E} \boldsymbol{R}=$ feed efficiency ratio.

Regarding to liver functions in Table (2), there were significant $(\mathrm{P}<0.05)$ increase in serum ALT and AST levels of the positive control group (rats with $\mathrm{CP}$ ) compared with the negative control group (normal rats). Feeding rats diets supplemented with vitamin D (group3) or Ca at the two different levels separately or in combination with vitamin $\mathrm{D}$, caused significant $(\mathrm{P}<0.05)$ decrease in serum ALT activity, compared to the positive control group. It was clear that, there was no significant difference in

\section{RESULTS}

Results illustrated in Table (1) show the effect of diets supplemented with calcium and vitamin D on body weight, feed intake and feed efficiency ratio of cerebral palsy rats. There were no significant changes in the initial body weight of all groups of rats. The final body weight (FBW) and body weight gain percent $(\mathrm{BWG} \%)$ were significantly $(\mathrm{P}<0.05)$ lowered in the positive control group (CP rats) compared to the control one. Diet supplementation with calcium and/or with vitamin D separately or in combination significantly increased the final body weight and body weight gain percentage, compared to the positive control group. It was also observed that the highest final body weight and body weight gain $\%$ were recorded at the group that fed on high calcium level (120mg) with vitamin D (group 7). Moreover, the mean feed intake was increased at all different treated groups compared to the positive control group. It was also observed that there were no significant differences in FER among the groups treated with calcium alone at $120 \mathrm{mg}$ and the groups fed on calcium (40 mg or $120 \mathrm{mg}$ ) in addition to vitamin $\mathrm{D}$ as compared to the negative control group. In conclusion, body weight gain of $\mathrm{CP}$ rats was increased as a result of ingestion of diets supplemented with calcium and Vitamin D in all tested groups. serum ALT concentration among all the tested groups. Moreover, there was no significant difference in serum AST level among the groups fed on $\mathrm{Ca}$ at the level of $40 \mathrm{mg}$ or $120 \mathrm{mg}$, also between the groups fed on $\mathrm{Ca}$ at the two tested levels in addition to vitamin D. There was no significant change in serum AST among the groups fed on $\mathrm{Ca}$ at the two tested levels with vitamin $\mathrm{D}$ and the negative control group. The highest improvements for liver functions were observed at the group of rats that fed on $\mathrm{Ca}$ at 
120mg with vitamin D. Thus, our study showed that ingestion of calcium and vitamin D improved serum liver functions concentration of cerebral palsy rats.

Table2. Effect of diets supplemented with $\mathrm{Ca}$ and Vitamin Don serum liver functions in rats with Cerebral Palsy

\begin{tabular}{|l|l|l|}
\hline \multicolumn{1}{|c|}{ Parameters } & ALT (U/L) & AST(U /L) \\
\hline Groups 1(-VeControl) & $18.80 \pm 1.12^{\mathrm{c}}$ & $33.93 \pm 1.57^{\mathrm{d}}$ \\
\hline Group 2 (+VeControl) & $60.26 \pm 4.56^{\mathrm{a}}$ & $70.40 \pm 3.03^{\mathrm{a}}$ \\
\hline Group 3(Vitamin D) & $44.76 \pm 4.72^{\mathrm{b}}$ & $58.66 \pm 3.17^{\mathrm{b}}$ \\
\hline Group 4 (Level 1 Ca) & $45.33 \pm 2.02^{\mathrm{b}}$ & $52.26 \pm 5.31^{\mathrm{cb}}$ \\
\hline Group 5 (Level 2 Ca) & $41.90 \pm 2.26^{\mathrm{b}}$ & $48.00 \pm 3.76^{\mathrm{cb}}$ \\
\hline Group6 (Level (1) Ca +Vt.D) & $44.00 \pm 1.73^{\mathrm{b}}$ & $43.23 \pm 2.42^{\mathrm{cd}}$ \\
\hline Group 7 (Level (2) Ca + Vt.D) & $38.73 \pm 3.12^{\mathrm{b}}$ & $41.13 \pm 4.49^{\mathrm{cd}}$ \\
\hline
\end{tabular}

*Values are expressed as means $\pm S E$.

*Values at the same column with different letters are significantly different at $P<0.05$.

Effect of diets supplemented with calcium and vitamin Don serum calcium, phosphorus and the ratio of calcium to phosphorus of cerebral palsy rats is shown in Table (3). Positive control group ( $\mathrm{CP}$ rats) had significant decrease $(\mathrm{P}<0.05)$ in the concentrations of serum calcium compared to the negative control group (normal rats) with mean values of $4 \pm 0.64 \mathrm{mg} / \mathrm{dl}$ vs $11 \pm 1.02 \mathrm{mg} / \mathrm{dl}$, respectively. When animals were fed on diets supplemented with vitamin D and/or calcium at the two different tested levels separately or in combination with vitamin D significantly increased the concentration of serum calcium, phosphorus and calcium to phosphorus ratio compared to the positive control group. There was no significant change in calcium and phosphorus levels between the groups fed on calcium at the two different levels ( $40 \mathrm{mg}$ or $120 \mathrm{mg}$ ), also between the groups fed on calcium at the two different levels in addition to vitamin D. In conclusion, the serum calcium and phosphorus concentrations of $\mathrm{CP}$ rats were increased as a result of ingestion of diets supplemented with calcium and vitamin Din all tested groups. Consequently, calcium to phosphorus ratio of $\mathrm{CP}$ rats was improved.

Table3. Effect of diets supplemented with Ca and vitamin D on serum calcium and phosphorus in rats with cerebral palsy

\begin{tabular}{|l|c|c|c|}
\hline \multicolumn{1}{|c|}{ Parameters } & Calcium (mg /dl) & Phosphorus (mg /dl) & Ca :P ratio \\
\hline Groups & $11 \pm 1.02^{\mathrm{a}}$ & $6 \pm 0.29^{\mathrm{a}}$ & 1.8 \\
\hline Group 2 (+Ve Control) & $4 \pm 0.64^{\mathrm{d}}$ & $3 \pm 0.55^{\mathrm{d}}$ & 1.3 \\
\hline Group 3(Vitamin D) & $7 \pm 0.12^{\mathrm{c}}$ & $4 \pm 0.21^{\mathrm{cb}}$ & 1.7 \\
\hline Group 4 (Level 1 Ca) & $8 \pm 0.19^{\mathrm{cb}}$ & $4 \pm 0.07^{\mathrm{c}}$ & 2.0 \\
\hline Group 5 (Level 2 Ca) & $8 \pm 0.11^{\mathrm{cb}}$ & $4 \pm 0.20^{\mathrm{cb}}$ & 2.0 \\
\hline Group6 (Level (1) Ca +Vt.D) & $9 \pm 0.55^{\mathrm{b}}$ & $5 \pm 0.25^{\mathrm{b}}$ & 1.8 \\
\hline Group 7 (Level (2) Ca+Vt.D) & $9 \pm 0.21^{\mathrm{b}}$ & $5 \pm 0.26^{\mathrm{b}}$ & 1.8 \\
\hline
\end{tabular}

*Values are expressed as means $\pm S E$.

*Values at the same column with different letters are significantly different at $P<0.05$.

The results in Table (4) illustrated the effect of diets supplemented with calcium and vitamin D on serum alkaline phosphatase and parathyroid hormone of $\mathrm{CP}$ rats. Cerebral palsy rats had a significant $(\mathrm{P}<0.05)$ increase in serum alkaline phosphatase and parathyroid hormone (due to $\mathrm{CP}$ induction) compared to the negative control ones. When CP rats were fed on basal diet and given orally vitamin D (group 3)showed significant reduction in alkaline phosphatase and parathyroid hormone concentrations in serum with mean values of $1281.00 \pm 21.00 \mathrm{U} / \mathrm{L}$ and $111.90 \pm 2.27 \mathrm{U} / \mathrm{L}$, respectively compared to the $\mathrm{CP}$ group( group 2). Ingestion of calcium at low(40 mg) or high (120mg) level separately or in combination with vitamin $\mathrm{D}$, caused more significant decrease $(\mathrm{P}<0.05)$ in serum alkaline phosphatase and parathyroid hormone compared to the positive control group.

In general there were significant decrease in serum alkaline phosphatase and parathyroid hormone among the groups given Vitamin D and the group given calcium at the two different levels. The most improvement in serum ALP and $\mathrm{PTH}$ were recorded in the group given calcium at $120 \mathrm{mg}$ in addition to vitamin D. Thus, our study showed that ingestion of diets supplemented with calcium and vitamin D improved serum ALP and PTH concentration of cerebral palsy rats. 
Table4. Effect of diets supplemented with Ca and vitamin D on serum ALP and PTH in rats with cerebral palsy

\begin{tabular}{|l|l|l|}
\hline Groups & Alkaline Phosphatase (U/L) & Parathyroid Hormone (U/L) \\
\hline Group1(-Ve Control) & $609.33 \pm 18.41^{\mathrm{fe}}$ & $44.83 \pm 5.91^{\mathrm{e}}$ \\
\hline Group 2 (+Ve Control) & $1611.33 \pm 26.73^{\mathrm{a}}$ & $148.56 \pm 3.50^{\mathrm{a}}$ \\
\hline Group 3 (Vitamin D) & $1281.00 \pm 21.00^{\mathrm{b}}$ & $111.90 \pm 2.27^{\mathrm{b}}$ \\
\hline Group 4 (Level 1 Ca) & $1139.00 \pm 23.57^{\mathrm{c}}$ & $99.00 \pm 1.47^{\mathrm{c}}$ \\
\hline Group 5 (Level 2 Ca) & $925.40 \pm 34.30^{\mathrm{d}}$ & $77.36 \pm 3.45^{\mathrm{d}}$ \\
\hline Group6 (Level (1) Ca +Vt.D) & $681.46 \pm 33.19^{\mathrm{e}}$ & $67.33 \pm 4.22^{\mathrm{d}}$ \\
\hline Group 7 (Level (2) Ca + Vt.D) & $553.53 \pm 75.38^{\mathrm{f}}$ & $49.13 \pm 3.69^{\mathrm{e}}$ \\
\hline
\end{tabular}

*Values are expressed as means $\pm S E$

*Values at the same column with different letters are significantly different at $P<0.05$.

Effect of diet supplemented with $\mathrm{Ca}$ and vitamin $\mathrm{D}$ on Bone mineral density and bone mineral content in rats with cerebral palsyis shown in Table (5) as well as dual energy X-ray Scan of cerebral palsy rats is illustrated in photoes 1-7. The mean bone mineral density of the positive control group was significantly $(\mathrm{P}<0.05)$ decreased, compared to the negative control rats (normal group). The diet supplementation with vitamin $\mathrm{D}$ or calcium at the two different levels separately or in combination with vitamin $D$ showed significantly $(\mathrm{P}<0.05)$ increased the mean value of bone mineral density, compared to the positive control group. There was no significant change in bone mineral density between the groups given calcium in the diet either at low or high level. However, there was a significant increase in bone mineral density for rats given calcium at high level with vitamin $D$ addition, compared to either the rats given calcium at the low level with of vitamin D or rats given vitamin $\mathrm{D}$ alone. The highest increase in the bone mineral density was observed for the groups given calcium at high level with vitamin D supplementation.

Regarding to bone mineral content, it was seen that there were no significant differences among all the treated groups compared to the negative and the positive control ones. Also, no significant change in the mean value of bone mineral content for the positive control group compare to the negative control group. It could be concluded that diet supplementation with calcium and vitamin $\mathrm{D}$ at the tested levels improved the bone mineral density for $\mathrm{CP}$ rats. The best improvement was seen when diet contains the highest level of $\mathrm{Ca}$ in addition to vitamin $\mathrm{D}$.

Table5. Effect of diet supplemented with Ca and vitamin D on Bone Mineral Density and Bone Mineral Content in rats with cerebral palsy

\begin{tabular}{|l|l|l|}
\hline \multicolumn{1}{|c|}{ Proups } & \multicolumn{1}{|c|}{$\begin{array}{c}\text { Bone Minerals } \\
\text { Density }(\mathbf{g} / \mathbf{C m} \text { 2) }\end{array}$} & \multicolumn{1}{|c|}{$\begin{array}{c}\text { Bone Mineral } \\
\text { Content } \\
(\mathbf{g m} / \mathbf{c m} \text { ) }\end{array}$} \\
\hline Group1(-Ve Control) & $0.08 \pm 0.003^{\mathrm{d}}$ & $0.35 \pm 0.10^{\mathrm{a}}$ \\
\hline Group 2 (+Ve Control) & $0.07 \pm 0.001^{\mathrm{e}}$ & $0.35 \pm 0.02^{\mathrm{a}}$ \\
\hline Group 3 (Vitamin D) & $0.09 \pm 0.001^{\mathrm{cd}}$ & $0.35 \pm 0.06^{\mathrm{a}}$ \\
\hline Group 4 (Level 1 Ca) & $0.10 \pm 0.002^{\mathrm{c}}$ & $0.26 \pm 0.04^{\mathrm{a}}$ \\
\hline Group 5 (Level 2 Ca) & $0.10 \pm 0.006^{\mathrm{b}}$ & $0.27 \pm 0.07^{\mathrm{a}}$ \\
\hline Group 6 (Level (1) Ca +Vt.D) & $0.10 \pm 0.003^{\mathrm{b}}$ & $0.27 \pm 0.00^{\mathrm{a}}$ \\
\hline Group 7 (Level (2) Ca + Vt.D) & $0.11 \pm 0.002^{\mathrm{a}}$ & $0.33 \pm 0.06^{\mathrm{a}}$ \\
\hline
\end{tabular}

*Values are expressed as means $\pm S E$

*Values at the same column with different letters are significantly different at $P<0.05$.

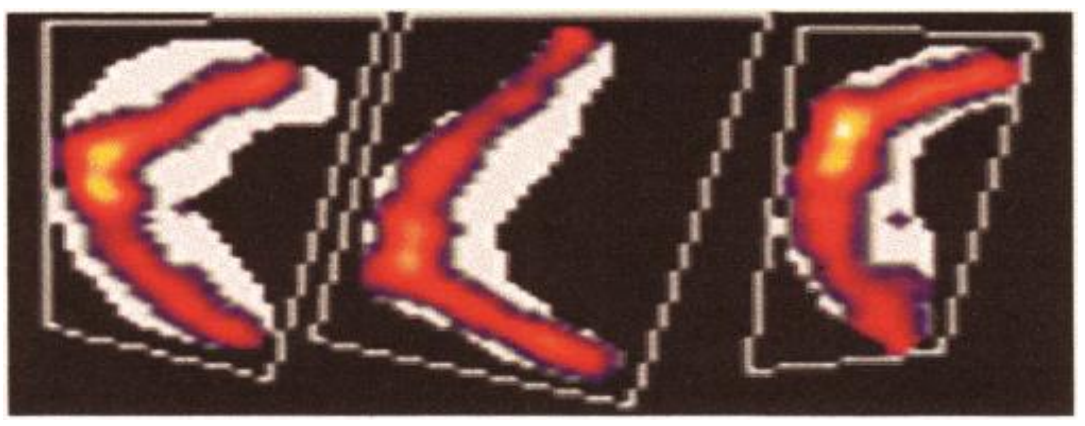

Photo1. Dual energy X-ray Scan of cerebral palsy rats from the negative control group (group1) 


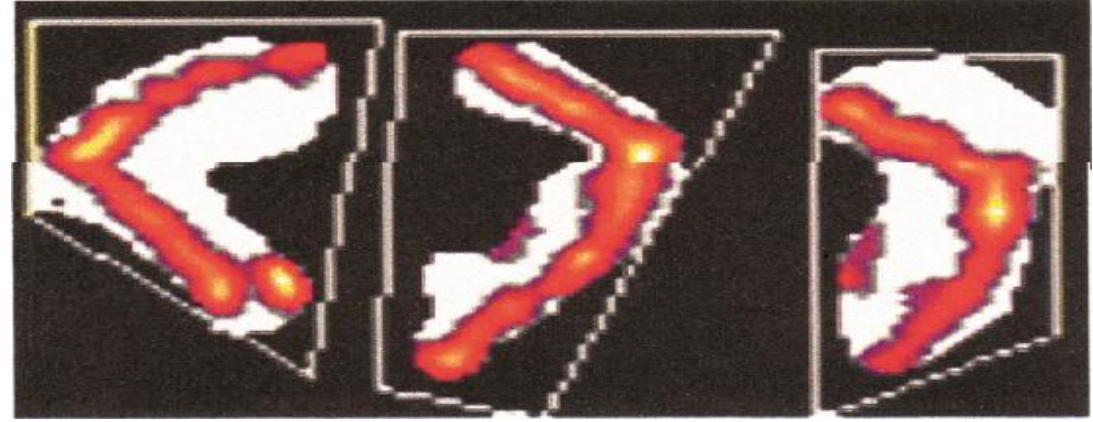

Photo2. Dual energy X-ray Scan of cerebral palsy rats from the positive control group (group 2)

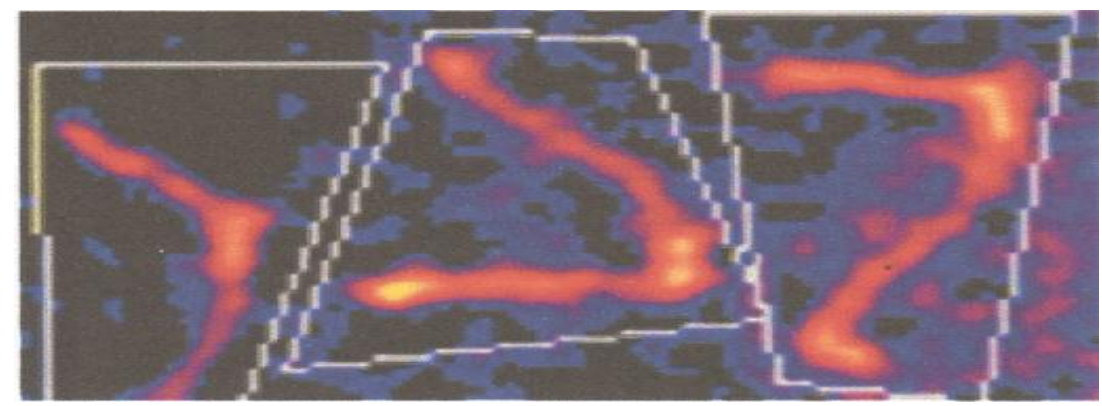

Photo3. Dual energy X-ray Scan of cerebral palsy rats fed on basal diet supplemented with vitamin D (group3)

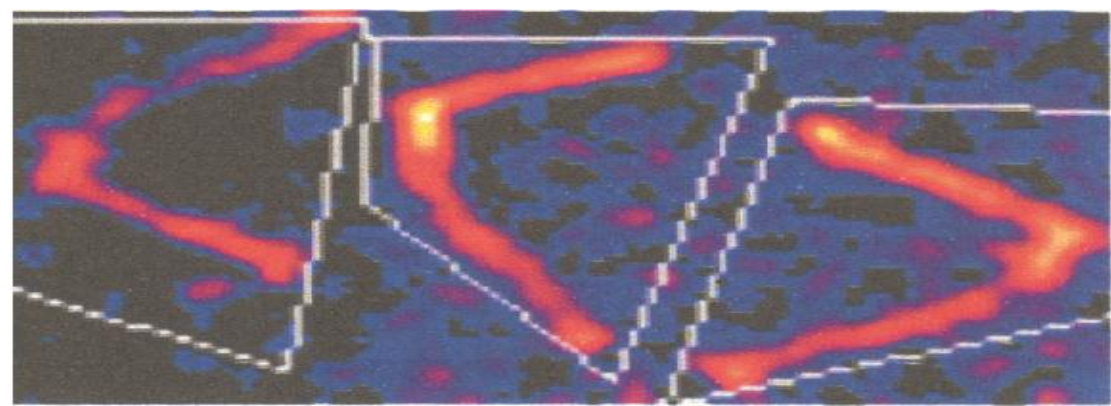

Photo4. Dual energy X-ray Scan of cerebral palsy rats fed on basal diet supplemented with level 1 Ca (group 4)

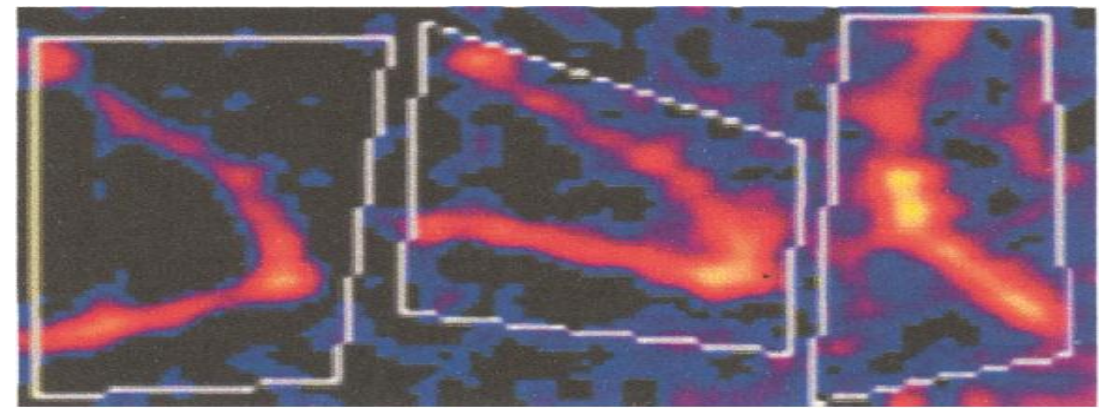

Photo5. Dual energy X-ray Scan of cerebral palsy rats fed on basal diet supplemented with level 2 Ca (group5)

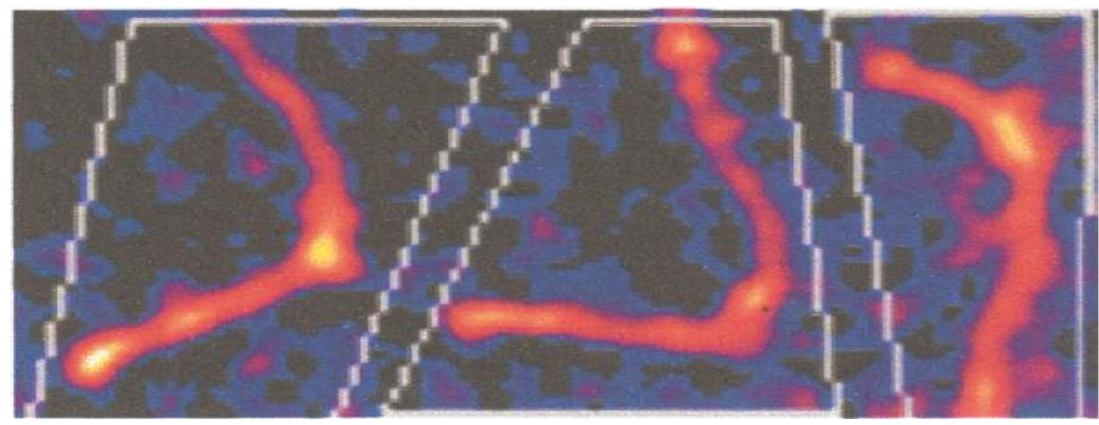

Photo6. Dual energy X-ray Scan of cerebral palsy rats fed on basal diet supplemented with level 1 Ca with Vt. D (group 6) 


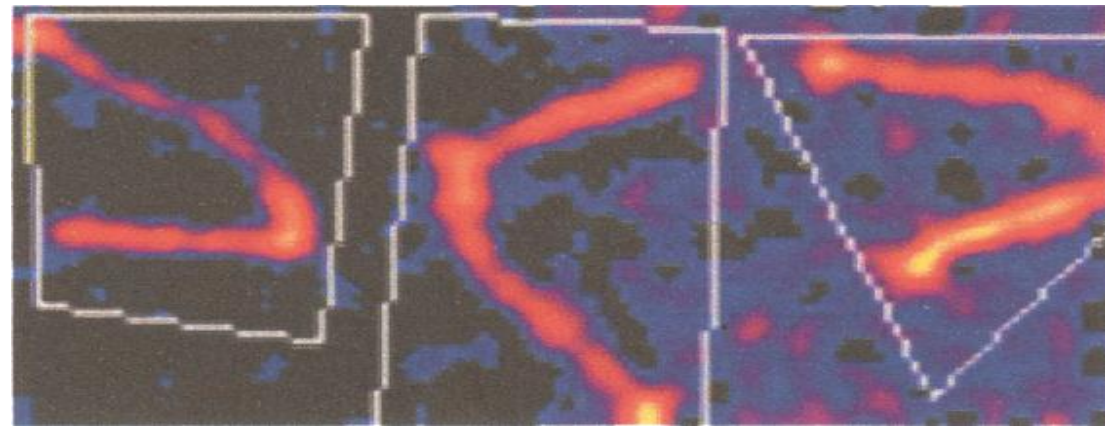

Photo7. Dual energy X-ray Scan of cerebral palsy rats fed on basal diet supplemented with level 2 Ca with Vt.D (group 7)

\section{DISCUSSION}

The cerebral palsy brain lesion can occur, to neonatal or at a later stage in a child's life. The true proportion of children affected antenatal is not known however, indicators of causes such as genetic predisposition prior to conception or infections encountered during pregnancy amongst others can be determined. For those infants who suffered their lesion or insult perinatally, only a fraction is associated with poor obstetric care during birth. The precise figure is unknown, as diagnosis cannot be made until developmental milestones are missed, however by the age of 5 years, $0.2 \%$ of all births will have cerebral palsy (Blairet al., 2018).

Children with CP are at risk for developing low bone quality and low-impact fractures. Important risk factors compromising bone health in this group are immobility, malnutrition and medication use for example antiepileptic drugs (Papadelis et al., 2018). Children with severe CP develop over the course of their lives clinically significant osteopenia. Unlike elderly adults, this is not primarily from true losses in bone mineral, but from a rate of growth in bone mineral that is diminished relative to healthy children (Toopchizadeh, et al., 2019).

Results of the current study indicated that the highest improvements for liver functions (ALT, AST, and ALP) were observed with the group of rats that fed on diet supplemented with $\mathrm{Ca}$ at $120 \mathrm{mg}$ in addition to vitamin D. This result is confirmed by the findings of Moghadam et al., (2018) who found that significant elevations in serum alkaline phosphatase levels were evident in all patient groups who are receiving phenytoin without giving any supplements. In 2018, it has been shown by Nair that concomitant use of antiepileptic drugs (AEDs) that induce microsomal P450 enzymes (e.g., phenytoin and phenobarbital) may enhance the production of a toxic metabolite, and hence the greater risk of heaptotoxicity with polypharmacy. On the other hand, Okwakpam, et al., (2018) suggested that there is no value in the routine performance of liver function tests in patients with epilepsy. However, such patients should be informed of the symptoms of hepatic dysfunction and asked to report for liver function tests should they have such symptoms.

The results of the current study indicated that diet supplemented with vitamin D and calcium at the highest-level increased serum calcium, phosphate concentrations, while the mean values of serum alkaline phosphatase level was decreased in the cerebral palsy (CP) rats. This result is confirmed by the findings of Mughal, (2018) who found that the mean serum calcium (Ca) and phosphate $(\underline{\mathrm{P}})$ levels were increased (from 2.17 to $2.35 \mathrm{mmol} / \mathrm{L}$ for $\mathrm{Ca}$ and from 1.13 to $1.66 \mathrm{mmol} / \mathrm{L}$ for P).However, the mean total alkaline phosphatase level was decreased from 1123 to $423 \mathrm{U} / \mathrm{L}$ among children and young adults with quadriplegic cerebral palsy. Some other studies (Choi and Seo, 2013, Lu et al., 2013 and Papadeliset. al, 2014) confirmed that calcium and vitamin D are critical regulators of bone remodeling, promoting weight-bearing activity are also preventive measures that required in the care for children and adults with $\mathrm{CP}$.

It has been shown in the current study that there was significant reduction in parathyroid hormone activities among rat groups given diets supplemented with vitamin D only, and the groups of rats were given diets supplemented with calcium at the two different levels in addition to vitamin $\mathrm{D}$. The most improvement in serum PTH concentration was recorded in the group given calcium at $120 \mathrm{mg}$ with vitamin D. These findings could be due to that PTH regulates blood calcium levels by releasing calcium from bone, and by stimulating calcium reabsorption by the kidney. Parathyroid hormone also stimulates the renal synthesis of $1,25(\mathrm{OH})_{2} \mathrm{D}$, thus increasing intestinal calcium absorption as stated by Kilpinen-Loisa et al., (2010). 
Sözenet al., (2017) found that inability to absorb adequate amounts of calcium for optimal bone health, as well as an increased susceptibility of falling, impaired muscle strength, and increased rates of bone loss can increase the risk of fracture. Kandhro et al., (2019) reported that lower levels of vitamin D are independently associated with an increased risk of falling in the elderly. In fact, supplementation with vitamin $\mathrm{D}$ has been shown to improve musculoskeletal function and reduce the risk of falling in elderly women. Stockton, et al., (2011) confirmed that by stating that human muscle contains vitamin $\mathrm{D}$ receptors that may lead to increasing muscle strength and improving stability. Also, another study by Kamberi et al., (2018) found that the combination of 700 units/day of vitamin D and $500 \mathrm{mg}$ of calcium (obtained through supplementation in addition to diet) was shown to reduce falls by as much as $65 \%$ over three years in less active women over the age of 65 . LeBoff et al., (2019) found that over 18 months, a trial of elderly french women found that the number of hip fractures was reduced by $43 \%$ and no vertebral fractures was reduced by $32 \%$ among women treated with calcium (1200 $\mathrm{mg} /$ day) and vitamin $\mathrm{D}$ (800 units/day) than among those who received placebo. Sandhu and Hampson, (2011) confirm that the best effect was seen with minimum doses of 1200 $\mathrm{mg}$ of calcium and 800 units of vitamin D daily and calcium, or calcium in combination with vitamin D supplementation, was effective in the preventive treatment of osteoporosis.

Concerning bone mineral density, the results of the current study indicated that diets supplementation with vitamin D and calcium at the two studied levels significantly improved the mean level of bone mineral density (BMD) in $\mathrm{CP}$ rats. Some studies revealed that fractures correlated with low body mass index (BMD), stiff joints, poor balance, and violent seizures (Snyder and Anderson, 2016). Leijten, et al., (2019) confirms that low BMD is a serious problem in children with severe $\mathrm{CP}$, significant determinants of low BMD were limited ambulation feeding difficulties, previous fracture, anticonvulsant use, and lower fat mass (measured at the triceps skinfold). Other studies by Kilpinen-Loisa et al., (2010) and Finbraten et al., (2015) suggested that most children with motor disability have low BMD and subsequently increased susceptibility to fractures.These results were in agreement with the findings in the present study. Mohammad et al., (2018) indicated that supplementation with vitamin $\mathrm{D}$ and calcium at the two studied levels significantly improved the mean level of bone mineral content (BMC) in CP rats.

It could be concluded from our study that ingestion of diets supplemented with calcium and vitamin $\mathrm{D}$ improved liver functions of cerebral palsy rats. Also, had beneficial effects on utilization of calcium and phosphorus and consequently, calcium to phosphorus ratio by increasing its concentrations in serum of $\mathrm{CP}$ rats. Thus, results of the current study recommend that vitamin $\mathrm{D}$ and calcium supplementation at the tested levels could be worthy treating for cerebral palsy patients.

\section{REFERENCES}

[1] Arslan, S. S.; Ilgaz, F.; Demir, N. and Karaduman, A. A. (2018): The Effect of the Inability to Intake Chewable Food Texture on Growth, Dietary Intake and Feeding Behaviors of Children with Cerebral Palsy. Journal of Developmental and Physical Disabilities, 30(2):205-214.

[2] Blair, E., Cans, C., and Sellier, E. (2018): "Epidemiology of the cerebral palsies". In Cerebral Palsy (pp. 19-28).Springer, Cham.

[3] Chapman, D.G.; Castilla, R. and Campbell, J.A. (1959): evaluation of protein in foods, a method for the determination of protein efficiency ratio. Can J Biochem. Phys. 37:679-86.

[4] Choi, M. and Seo, J. (2013): " Effect of taurine feeding on bone mineral density and bone markers in rats", In Taurine 8, Springer, New York, (776): 51-58.

[5] El- Adawy, A. (1986):Msc studies on some acoustical and physical properties of yttria stabilized zirconia refractories before and after irradiation. Fac. Sci, Men.,Univ., 77-110.

[6] Fogg, D. N. and Wilkinson, A. N. (1958):"The colorimetric determination of phosphorus" Analyst, 83(988), 406-414.

[7] Finbraten, A.; Syversen, U.; Skranes, J.; Andersen, G.; Stevenson, R. and Vik, T.(2015): "Bone mineral density and vitamin D status in ambulatory and non-ambulatory children with cerebral palsy", Osteoporosis International,;26(1):141-50.

[8] Gosling, P. (1986): "Analytical reviews in clinical biochemistry: calcium measurement", Annals of clinical biochemistry, 23(2), 146156.

[9] Henderson, J. E.; Shustik, C.; Kremer, R.; Rabbani, S. A.; Hendy, G. N.; Goltzman, D. and Goltzman, D. (1990): "Circulating 
concentrations of parathyroid hormone- like peptide in malignancy and in hyperparathyroidism", Journal of Bone and Mineral Research, 5(2), 105-113.

[10] Kandhro, F., Dahot, M. U., Naqvi, A., Habib, S., and Ujjan, I. U. (2019).Study of Vitamin D deficiency and contributing factors in the population of Hyderabad, Pakistan. Pakistan Journal of Pharmaceutical Sciences, 32(3)

[11] Kamberi, F., Stramarko, Y., Subashi, B., and Sinanaj, G. (2018): "Women with osteoporosis present their quality of life" Three cases from Vlore, Albania. Arch Community Med Public Health, 4(2), 069-072.

[12] Kilpinen-Loisa, P. (2010): "Bone health and vitamin $\mathrm{D}$ status in children with motor disability and adults with intellectual disability".

[13] LeBoff, M. S., Donlon, C. M., Chou, S. H., Cook, N., Buring, J., and Manson, J. E. (2019): "Vitamin D and Omega-3 Fatty Acid Trial 2017: Addressing Effects on Muscle and Bone. In Nutritional Influences on Bone Health (pp. 11-23). Springer, Cham.

[14] Leijten, A. D., Hampsink, B., Janssen, M., Klein, W. M., \&Draaisma, J. M. (2019): "Can digital X-ray radiogrammetry be an alternative for dual-energy X-ray absorptiometry in the diagnosis of secondary low bone quality in children?". European Journal of Pediatrics, 19.

[15] Lee, A. W., and Cho, S. S. (2015). Association between phosphorus intake and bone health in the NHANES population. Nutrition journal, 14(1), 28.

[16] Lu, M.; Farnebo, L. O.; Bränström, R. and Larsson, C. (2013): Inhibition of parathyroid hormone secretion by caffeine in human parathyroid cells. The Journal of Clinical Endocrinology and Metabolism, 98(8), E1345E1351.

[17] Mughal, M. Z. (2018): "Bone Health in Immobile Adolescents. In A Practical Approach to Adolescent Bone Health". (pp. 219-241). Springer, Cham.

[18] Mohammad, S. H., Hunter, R. L., Tatarski, R. L., Butwin, A. N., and Evans, K. D. (2018): "Assessing Cortical Thickness in Human Tibiae With Sonographyvs Computed Tomography" A Pilot Study. Journal of Diagnostic Medical Sonography, 34(3), 170-179.

[19] Moghadam, M. N., Teimouri, A., Khajeh, A., and HOSEINI, S. B. (2018): "Bone metabolism disorder in epileptic children. Iranian journal of child neurology, 12(2), 17.

[20] Nair, P. P. (2018):"Status Epilepticus in Special Situations". In Status Epilepticus: Practical Guidelines in Management (pp. 72-79).
[21] Nikam, R. M.; Choudhary, A. K.; Kandula, V.; \& Averill, L. (2019): Neuroimaging Pathology in Cerebral Palsy. Cerebral Palsy, 1-39.

[22] Okwakpam, F. N., Omeodu, S., and Uwakwe, A. A. (2018): "The Effects of Diazepam on Selected Blood Enzymes Activity and Prostate Specific Antigen of Adult Male Wistar Rats". American Journal of Biomedical Sciences, 10(3).

[23] Papadelis, C.; Ahtam, B.; Nazarova, M.; Nimec, D.; Snyder, B.; Grant, P. E. and Okada, Y. (2014): "Cortical somatosensory reorganization in children with spastic cerebral palsy", a multimodal neuroimaging study. Frontiers in human neuroscience, 8, 725.

[24] Papadelis, C.; Butler, E.E.; Rubenstein, M.; Sun, L.; Zollei, L.; Nimec, D. and Grant, P.E. (2018): Reorganization of the somatosensory cortex in hemiplegic cerebral palsy associated with impaired sensory tracts. NeuroImage: Clinical, 17:198-212.Peacock, M. (2010): "Calcium metabolism in health and disease", Clinical Journal of the American Society of Nephrology, 5(S. 1): S23-S30.

[25] Reeves, P.G.; Nielsen F.H. and Fahmy G.G. (1993): AIN-93. Purified diets for laboratory rodents : Final report of the American Institute of Nutrition adhocwriling committee on the reformulation of the AIN-76 A Rodent diet. J. Nutrition, 123: 1939-151.

[26] Roy, S.E. (1970): colorimetric method of serum alkaline phosphatase. Journal of Clinical Chemistry, 16:431-432.

[27] Snedecor, G. W. and Cochran, W. G. (1980): "Statistical Methods Iowa State University Press, Ames", Statistical methods. 7th ed.. The Iowa State University Press, Ames.

[28] Sözen, T.; Özışık, L. and Başaran, N. Ç. (2017): "An overview and management of osteoporosis", European journal of rheumatology, 4(1), 46.

[29] Sandhu, S. K. and Hampson, G. (2011): "The pathogenesis, diagnosis, investigation and management of osteoporosis", Journal of clinical pathology, 64(12), 1042-1050.

[30] Stockton, K.; Mengersen, K.; Paratz, J. D.; Kandiah, D. and Bennell, K. L. (2011): "Effect of vitamin D supplementation on muscle strength: a systematic review and metaanalysis", Osteoporosis international, 22(3), 859-871.

[31] Snyder, B. and Anderson, M. (2016): "Evaluation and Management of Pathologic Femur Fractures in Children", In Pediatric Femur Fractures: 195-213. Springer, Boston, MA. 
[32] Thefeld, W.(1974): Determination of serum glutamic oxaloacetictransminases (GOT) and pyruvic transminases (GPT). Dt. Med. Wschr., 99:343.

[33] Toopchizadeh, V., Nabiollahi, R., Barzegar, M., Shiva, S., Eftekharsadat, B., and Ghojazadeh, M. (2019): "Bone Mineral Density among Children with Cerebral Palsy. Physical
Medicine,
Rehabilitation,
and Electrodiagnosis, 1(1), 37-43.

[34] Yadong, Y.; Liang, L.; Shao, X.; Tian, F. and Sun, Q. (2013). Establishing a rat model of spastic cerebral palsy by targeted ethanol injection. Neural regeneration research, 8(34), 3255 .

Citation: Hoda S. Ibrahim, Naeem M. Rabeh and Fatma N. Ahmed. Calcium and Phosphorus Utilization on Rats with Induced Cerebral Palsy. ARC Journal of Nutrition and Growth. 2019; 5(1):19-28. DOI: dx.doi.org/ 10.20431/2455-2550.0501004.

Copyright: (C) 2019 Authors. This is an open-access article distributed under the terms of the Creative Commons Attribution License, which permits unrestricted use, distribution, and reproduction in any medium, provided the original author and source are credited. 